\title{
The Function of Tax Amnesty to Strengthen Corporate Taxes, Case Study of Indonesia's Manufacturing Industry
}

\author{
Agoestina Mappadang
}

\begin{abstract}
The purpose of this study was to examine and analyze: the effect of market performance on corporate tax, examine and analyze the influence of corporate governance on corporate tax, the effect of tax audit on corporate tax, the role of Tax amnesty in moderating relations between market performance and corporate tax, the role of Tax amnesty in moderating corporate governance relationship, and corporate tax, Tax amnesty in moderating the relationship between tax audit and corporate tax
\end{abstract}

This research model uses panel regression. The unit of analysis is an open company (corporate taxpayer), with a purposive sampling sample, namely taxpayers registered in the Large Taxpayers KPP Two of 44 companies in the period 20142017

The results showed: Market performance has a positive effect on corporate tax, this shows that the higher market performance as measured by tobins $q$, the corporate tax will increase; Corporate governance has a positive effect on corporate tax, this shows that the higher the corporate governance index, the corporate tax will increase; Tax audit has a positive effect on corporate tax, this shows that the more there is an examination of the tax, the corporate tax will increase; Tax amnesty strengthens the influence of market performance on corporate tax, because the tax amnesty has a positive influence on the relationship between market performance and corporate tax with a type of pure moderation; Tax amnesty strengthens the influence of corporate governance on corporate tax, tax amnesty has a positive influence on the relationship between corporate governance and corporate tax with a type of pure moderation; Tax amnesty strengthens the effect of tax audits on corporate tax, because tax amnesty has a positive influence on the relationship between tax audits and corporate tax with pure types of moderation

Moderation of tax amnesty can strengthen the influence of market performance, corporate governance and tax audit on corporate tax.

Index Terms - market performance, corporate governance governance, tax audit, corporate tax and tax amnesty.

\section{INTRODUCTION}

\section{A. Background Research}

Tax is the backbone of state revenue. The significant role of taxes is seen in tax revenue data for 2015-2019 as set out in Table 1. The table shows the average contribution of tax revenue to the state budget (APBN) during the period amounted to $81.3 \%$.

The increase in the percentage of the tax budget in the APBN is not balanced with the realization of the targeted revenue achievement each year by the Government to the Directorate General of Taxes as a tax collector because the consistent achievement of the Tax ratio has fallen. Tax ratio is a percentage of tax revenue to GDP which is a measure of the government's ability to collect taxes. High and low tax ratios are often characterized as the implications of the strength of the tax system in a country. In Fig. 1, it can be seen that the decline in Indonesia's tax ratio from 2010 to 2019.

TABLE 1: The Role of Tax in the State Budget (in billions of rupiah)
\begin{tabular}{|c|c|c|c|}
\hline & APBN & Tax & $\%$ \\
\hline 2015 & 1496047 & 1240419 & 82.913 \\
\hline 2016 & 1546947 & 1284970 & 83.065 \\
\hline 2017 & 1654746 & 1343530 & 81.193 \\
\hline 2018 & 1928110 & 1518790 & 78.771 \\
\hline 2019 & 2029418 & 1643084 & 80.963 \\
\hline average & & & 81.381 \\
\hline
\end{tabular}

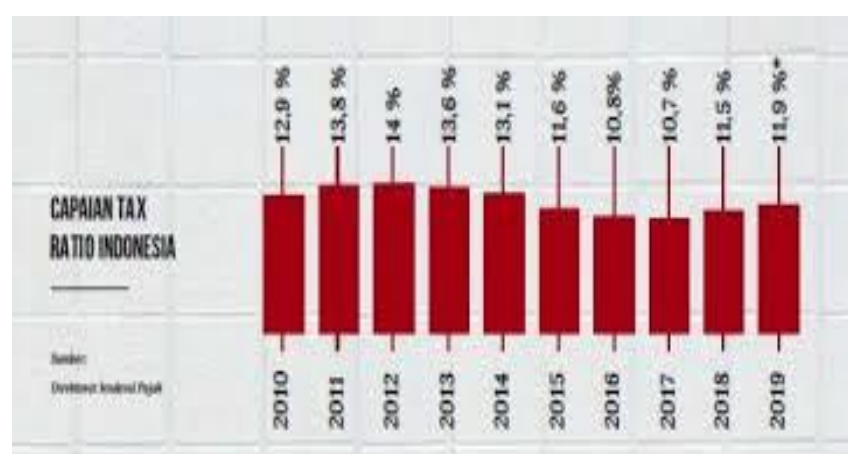

Fig. 1. Indonesian Tax Ratio Achievement Source: Directorate General of Tax

Indonesia's collapse in the tax ratio between Asia-Pacific countries is evidenced by a report released in 2019 by the Organization for Economic Co-operation and Development (OECD). The OECD with the Asian Development Bank (ADB), the Pacific Islands Tax Administrators Association (PITAA), and the Pacific Community (SPC), as well as financial support from the European Union. Register tax ratios in 17 countries joining the OECD covering the Asia and Pacific region, as shown in Fig. 2.

The inability to achieve the target revenue that was imposed and also the still low Tax Ratio, made the Directorate General of Taxes make a strategic effort in collecting taxes in 2016 based on Law Number 11 of 2016 concerning Tax Amnesty. Tax amnesty is a forgiveness program given by the government to taxpayers including the elimination of taxation that should be owed, the elimination of tax administration sanctions, as well as the elimination of criminal sanctions in the field of taxation on assets obtained in 2015 and previously that have not been reported in the 
annual notification letter (SPT), by paying off all tax arrears owned and paying a ransom. In the short term, the tax amnesty program aims to increase state revenue, while in the long term it aims to increase taxpayer compliance in meeting tax obligations. Tax amnesty is a program that is carried out within a certain period of time to provide an opportunity for taxpayers to pay tax owed that has not been paid and / or tax that should be owed, by providing compensation in the form of exemption from sanctions (in the form of interest or penalties) and criminal prosecution [1].

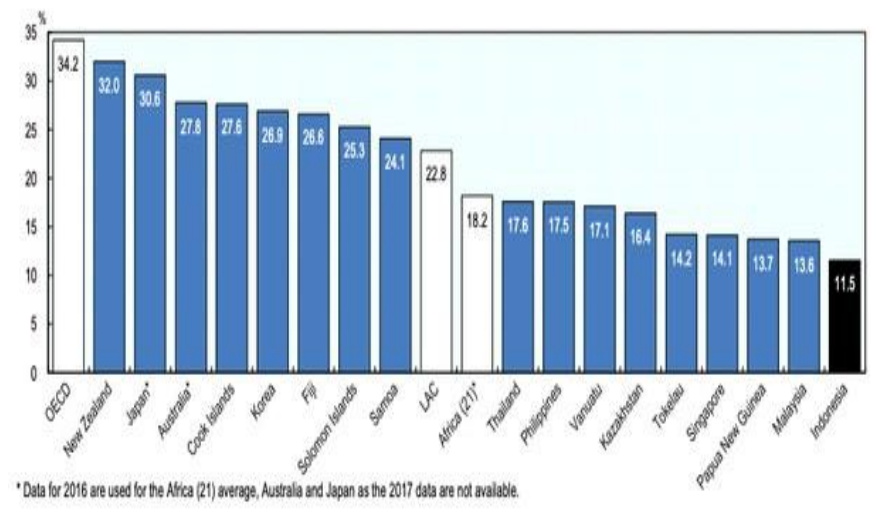

Fig. 2. Tax Ratio ComparisonSource: Directorate General of Tax

This research was conducted as an effort to find out whether the tax amnesty program has an influence on the relationship of market performance, corporate governance and tax audits with tax payments of corporate taxpayers before and after joining the Tax amnesty program.

The contribution amount of corporate tax payments is calculated using a CTTOR (corporate tax to turn over ratio) measurement, which compares corporate tax payments compared with the number of sales made by taxpayers in the year. This is in accordance with the Circular of the Director General of Taxes Number SE-96 / PJ / 2009 concerning the ratio of total benchmarking and instructions for its use as well as in the Circular of the Director General of Taxes Number SE - 02 / PJ / 2016 Regarding the Making of the Behavioral Benchmark Model and its Follow Up. Second Circular of the Director General of Taxes was issued to improve the efficiency and effectiveness of taxpayer compliance monitoring.

In addition to using the measurement of corporate tax to Turn Over Ratio (CTTOR), taxpayers' corporate tax payments can also be measured using an effective tax rate (ETR) measurement. ETR is the company's effective tax rate which can be calculated from income tax expense (current tax expense) which is then divided by profit before tax. Effective tax rates indicate the effectiveness of a company's tax management [2]. From this definition the effective tax rate (ETR) has the objective to find out the percentage change in actual tax pay to the commercial profit obtained. The tax burden used only uses the current tax burden because at the present tax burden it is possible to choose policies related to taxation and accounting [3].

The results of empirical studies that have been conducted show that market performance is one of the factors that determine tax revenue. There is a positive relationship between the company's market performance with economic growth and tax revenue. The development of the open company market affects tax revenue. From these results it shows that government tax revenue which is the main source of revenue for the government is very dependent on the market performance of publicly listed companies [4]. Market performance will increase corporate tax revenue. Market performance is a critical factor for the survival of companies, thus affecting corporate taxes. [4] shows that government tax revenue depends on the company's market performance. This is supported by [5]-[9].

Corporate governance and tax policy complement each other and can provide more efficient alternatives than implementing separate schemes [10]. According to the [11], corporate governance $(\mathrm{CG})$ is a set of regulations governing the relationship between shareholders, company management, creditors, government, employees and other internal and external stakeholders relating to rights -rights and obligations. Corporate Governance implies as a system that guarantees the rights and obligations of the company management and other parties outside the company management to run well, fairly and transparently

This tax supervision is carried out by the Directorate General of Tax (DGT). According to [1] the supervisory function carried out by the DGT includes research, inspection and investigation activities in the taxation field which must be continuously carried out. Researches related to the role of tax supervision have been carried out by researchers. Among these are conducted by [12], [13].

Originality or renewal of this study with other studies, namely the tax amnesty policy variable. Tax Amnesty is given the role of moderation on the influence of the relationship of market performance, corporate governance and tax audits with taxpayers' corporate tax payments, before and after the Tax amnesty program. This study measures tax amnesty based on taxpayer participation in tax amnesty which is measured using an interval scale.

The originality of this research is to use the variable tax amnesty as a moderating variable that can affect the relationship between market performance, corporate governance, tax audits and corporate taxes. In general, the main objective of this study is to examine the effectiveness of tax amnesty as a policy that can increase tax revenue.

The formulation of the problem in this study are as follows:

1. Does tax amnesty strengthen the effect of market performance on corporate tax?

2. Does tax amnesty strengthen the influence of corporate governance on corporate tax?

3. Does tax amnesty strengthen the effect of tax audits on corporate tax?

\section{LITERATURE REVIEW}

\section{A. Conceptual Framework}

Tax payment is one of the crucial points in a series of taxation systems in Indonesia that adhere to a self-assessment system (SAS). In SAS it is the taxpayer who is obliged to calculate, pay and report on his own tax obligations. Payment of taxes is the fulfillment of tax obligations by taxpayers (SE Director General of Taxes, 2009). The measurement of tax obligation fulfilment by taxpayers used is the Corporate tax 
to Turn Over Ratio (CTTOR) which is the ratio of income tax payable to sales.

Market performance is a critical factor for the survival of companies, thus affecting corporate taxes. [4] research (2017) shows that government tax revenue depends on the company's market performance. This is supported by [6], [7], [8] and [9].

Good corporate governance (GCG) according to the National Committee on Governance Policy (KNKG) is one of the pillars of the market economy system. Corporate governance is closely related to trust both in the companies that implement it and in the business climate in a country. The implementation of GCG encourages the creation of healthy competition and a conducive business climate. A number of studies have been conducted on the effect of corporate governance on corporate taxation, among others, conducted by [14], [15] [16] and [17]that the impact of effective corporate governance will have a positive effect on corporation tax.

The tax audit which is part of the tax supervision is carried out by the Directorate General of Tax (DGT). The supervisory function carried out by the DGT includes research, inspection and investigation activities in the field of taxation which must be continuously carried out. The researchers managed to obtain empirical evidence that tax control affects corporate taxes such as [18], [19].

Tax amnesty is a program that is carried out within a certain period of time to provide an opportunity for taxpayers to pay tax owed that has not been paid and / or tax that should be owed, by providing compensation in the form of exemption from sanctions (in the form of interest or penalties) and criminal prosecution [1]. Tax amnesty in this study is measured by the periodization of taxpayer participation in participating in the tax amnesty program according to the period of filing a Tax Amnesty application in accordance with Law Number 11 of 2016 concerning Tax Amnesty. Researchers determine that the taxpayer with participation in a certain period, where there are 3 time periods specified namely period I (01 July 2016 - 30 September 2016), period II (01 October 2016 - 31 December 2016), period III (01 January 2017 - March 31, 2017), was measured using an interval scale on the motivation of taxpayers in the time period of participation in Tax Amnesty. Motivation is psychological processes that cause stimulation, direction, and persistence of an activity carried out voluntarily that is directed at a goal in accordance with the theory of Planned Behavior . In the perspective of fulfilling taxpayers with Law Number 11 of 2016 concerning Tax Amnesty, there is a motivation for taxpayers to be able to immediately submit a Statement of Assets as a form of participation in the Tax Amnesty program.

This study also uses a control variable that is analyzing the effect of financial conditions, earnings management and company size on corporate tax.

\section{B. Hypothesis Testing Design}

\section{Tax amnesty as a moderating effect of market performance} on corporate tax

Tax amnesty as a moderating effect of market performance on corporate tax. Tax amnesty is a tax amnesty program by uncovering assets and paying ransom as stipulated in Law
Number 11 of 2016. The government-initiated program is in effect since the beginning of July 2016 and ends at the end of March 2017, aimed at increasing tax revenue through tax amnesty to Indonesian people who have assets but have not been reported, both these assets are abroad and within the country. [20].

Market performance is a critical factor for the survival of companies, thus affecting corporate taxes. [4] shows that government tax revenue depends on the company's market performance. This is supported by [6], [7], [8] and [9]. Research [21] and [22] have proven that tax amnesty will increase corporation tax. Various benefits of Tax amnesty mentioned above can be concluded that the tax burden to be borne by the company will be much lighter and this will indirectly ease the company's financial burden and ultimately help improve company performance, so that market performance increases when added to tax amnesty it will increase corporate taxes. So the existence of tax amnesty as a moderating will strengthen the relationship between market performance and corporate tax. [23] the long-term impact of amnesty tax amnesty has a short-term or long-term impact on the income of the Russian Federation. [24]The function of tax amnesty in overcoming tax evasion in Nigeria The function of tax amnesty is to increase government revenue to meet the daunting challenges in dealing with slow growth rates in trade and investment. [25] improve tax administration to emphasize maximizing revenue Tax amnesty can improve the tax administration system. [26]. Analyzing whether tax amnesty is a good policy Tax amnesty will increase shortterm income

Researchers have an opinion that tax amnesty will strengthen the effect of market performance on corporate tax. Thus the researcher formulates the hypothesis proposed in this study are as follows:

H1: Tax amnesty reinforces the positive influence of market performance on corporate tax

2. Tax amnesty as a moderating influence of corporate governance on corporate tax

Tax amnesty is a tax amnesty program by uncovering assets and paying ransom as stipulated in Law Number 11 of 2016. The government-initiated program is in effect since the beginning of July 2016 and ends at the end of March 2017, aimed at increasing tax revenue through tax amnesty to Indonesian people who have assets but have not been reported, both these assets are abroad and within the country. [20].

According to [30].Good Corporate governance is a system, process, and set of rules that govern the relationships between various stakeholders, namely the relationship between shareholders, the board of trustees, and the board of directors for the achievement of organizational goals. According to [31] many tax problems in Indonesia are caused by agency problems in companies. In this case there is a difference in interests between management and the owner of the company where management is more concerned with his own interests, without regard to what is desired by the company owner, which is one of them is tax management. According to [31] with the existence of Good Corporate Governance, it is expected to be able to overcome agency problems in the company and maximize tax management. In addition, 
companies that implement Good Corporate Governance will get various benefits such as improving company performance, returning investor confidence and shareholders will be satisfied with the company's performance.

The influence of corporate governance on corporate taxation is among others conducted by [14], [15] [16] and [17] that the impact of effective corporate governance will have a positive effect on corporate tax corporate impact Effective governance will have a positive effect on corporate tax.

Companies that implement Tax amnesty for assets and liabilities that have not been reported will increase investor confidence in transparency and accountability. This is because the more transparent and accountable a company is, the level of public trust in the information of the company's financial statements will be higher, so that the interest of the public to invest their funds in the company will be higher. This can be seen in the expectation of high future cash flow and high profitability. With the high profitability generated by the company, tax revenues will rise. Research [21] and [22] have proven that tax amnesty will increase corporation tax

Research [23], [24], [25], [26] explain the effect of tax amnesty policy will increase tax revenue in the short term, so companies that already have good corporate governance, if added to the tax amnesty policy, will increase corporate tax Researchers have an opinion that tax amnesty will strengthen the influence of corporate governance on corporate tax. thus the researcher formulates the hypothesis proposed in this study are as follows:

\section{H2: Tax amnesty reinforces the positive influence of corporate governance on corporate tax}

3. Tax amnesty as a moderating relationship between the tax audit and corporate tax

Tax amnesty as a moderating relationship between the tax audit and corporate tax. According to Law Number 11 Year 2016 regarding Tax Amnesty, what is meant by Tax Amnesty is the abolition of taxes that should be owed not subject to tax administration sanctions and criminal sanctions in the field of taxation, by uncovering assets and paying ransom as stipulated in the law.

In addition, Article 18 of the Law states that, in the event that a Taxpayer who has obtained a Certificate is then found that data and / or information regarding Assets that have not been or have not been disclosed in the Declaration, the said Assets are considered as additional income received or obtained Taxpayers when the data and / or information regarding the said assets are found. The researchers managed to obtain empirical evidence that tax control affects corporate taxes, such as [18], [19].

According to [21]) the Tax amnesty program organized by the Turkish government has reduced the workload of administrators, tax court bodies and increased corporate taxes. This happens because the participants of the Tax Amnesty have submitted a certificate of ownership along with the evidence of the attachments making it easier for administrators to supervise and verify the assets of the Taxpayer. Tax amnesty as a moderator will be able to strengthen the positive effect of tax audits on corporate tax
Research [23], [24], [25], [26]explain the effect of tax amnesty policy will increase tax revenue, so companies that have been audited are part of from tax control if added to the tax amnesty policy, it will increase corporate tax.

Researchers have an opinion that tax amnesty will strengthen the effect of tax audits on corporation tax. thus the researcher formulates the hypothesis proposed in this study are as follows:

\section{H3: Tax amnesty reinforces the positive effect of tax audits on corporate tax}

\section{RESEARCH METHOD}

\section{A. Research design}

This study analyzes the effect of tax amnesty moderation on market performance, corporate governance and tax assessment of corporate tax. Referring to the proposed hypothesis, the variables according to their position are as follows: In addition there are moderating variables namely tax amnesty, with control variables including financial condition, company size and earnings management.

The research data is the period from 2014 to 2017 with an analysis unit of manufacturing industry companies that go public or public companies listed on the Indonesia Stock Exchange (IDX) that carry out tax amnesty.

\section{B. Determination of Population and Samples}

The population frame is a taxpayer registered in the manufacturing industry listed on the IDX of 141 manufacturing industry companies. The sampling method is a purposive sampling method where the sample is selected using certain criteria. Criteria taken from the population are all manufacturing companies in the period 2014-2017 whose shares are listed on the Indonesia Stock Exchange. The criteria carried out are as follows:

1. Manufacturing industry companies that were consistently listed on the IDX during the 2014-2017 period.

2. The company has an annual financial statement complete with the financial statement period ending on December 31 .

3. Have a complete financial statement document (audited financial statements and company annual reports published and the data can be accessed by the public).

4. Participate in the tax amnesty period.

\section{Variable Operational Definitions and Measurements}

This study consisted of 8 variables with different positions. Each is as follows: corporate tax as the dependent variable; with 3 independent variables which include: Market performance, Corporate governance, and tax audits. Tax amnesty as a moderating variable and 3 control variables for corporate tax: financial condition, company size, and earnings management.

\section{Variabel Dependen}

\section{Corporation tax}

Corporate tax measurement in this study uses corporate tax to Turn Over Ratio (CTTOR) which is the ratio of income tax payable to sales. CTTOR value shows the amount of income tax payable in a year relative to sales made by the company. 
The greater CTTOR shows the greater proportion of the company's sales proceeds that are used to pay income tax. CTTOR is calculated as follows: (SE Director General of Tax no. SE 96 / PJ / 2009).

\section{CTTOR = Income Tax $/$ sales X 100\%}

Thus the corporation tax variable is a ratio scale variable

\section{E. Independent Variables}

\section{1) Market Performance}

Market performance is measured using Tobin-Q. Tobin-Q reflects the comparison between the market value of a company with the total book value of assets. The Tobin-Q formula [28]; is as follows:

Tobin- $Q=$ (total market value+total book value of liabilities $) \div$ Total book value of assets

total market value $=$ total outstanding shares $*$ current share's price

Thus, the Market Performance variable is a ratio scale variable.

\section{2) Corporate governance}

The measurement of corporate governance in this study uses the ASEAN corporate governance scorecard which refers to the OECD principle consisting of 179 disclosure indicators including: 25 items of shareholder rights, 17 items of equality to shareholders, 21 items of stakeholder roles, 40 items of disclosure and transparency, and 76 items for board responsibilities. The steps taken are:

1. Make a list of disclosures. The list is arranged in the form of a list of disclosure items, with each item provided with an answer regarding the status of the disclosure in the relevant report.

2. Determine the disclosure index of principles applied to the company based on the list of disclosures. In determining the index, this is done as follows:

- The disclosure score is dichotomous, where a disclosure item is given a score of 1 if disclosed and a score of 0 if not disclosed.

- $\quad$ The scores obtained are added up to get the total score

- Index calculation is done by dividing the total score by the expected total score and then multiplying by the maximum points that have been set for each principle.

TABLE 2: Composition and Structure in the Asean Corporate Governance Scorecard

\begin{tabular}{|l|c|c|c|}
\hline OECD Principle & $\begin{array}{l}\text { Number of } \\
\text { question }\end{array}$ & $\begin{array}{l}\text { Weight (as a \% } \\
\text { of total score) }\end{array}$ & $\begin{array}{l}\text { Maximum } \\
\text { Attainable Score }\end{array}$ \\
\hline $\begin{array}{l}\text { Rights of } \\
\text { Shareholder }\end{array}$ & 25 & 10 & 10 point \\
\hline $\begin{array}{l}\text { Equitable point } \\
\text { Treatment of } \\
\text { Shareholder }\end{array}$ & 17 & 15 & 10 point \\
\hline $\begin{array}{l}\text { Role of } \\
\text { Stakeholder }\end{array}$ & 21 & 10 & 25 point \\
\hline $\begin{array}{l}\text { Disclosure and } \\
\text { Transparency }\end{array}$ & 40 & 25 & 40 point \\
\hline $\begin{array}{l}\text { Responbility of } \\
\text { the Board }\end{array}$ & 76 & 40 & 15 \\
\hline
\end{tabular}

Measurement of the ASEAN corporate governance scorecard index is calculated by the formula:

CG Scorecard : (Number of Items Disclosed) / (Number of items to be disclosed)

\section{3) Tax Audit}

The tax audit uses the audit indicators that are available in the financial statements of publicly listed companies, using the Dummy Variable where 1 (one) for the company under investigation and 0 (zero) for companies that have not been audited. Scala for tax audits is nominal [12].

\section{F. Moderation Variables}

Tax amnesty in this study is measured by the periodization of taxpayer participation in participating in the tax amnesty program according to the period of filing a Tax Amnesty application in accordance with Law Number 11 of 2016 concerning Tax Amnesty. Researchers determine that the taxpayer with participation in a certain period, where there are 3 time periods specified namely period I (01 July 2016 30 September 2016), period II (01 October 2016 - 31 December 2016), period III (01 January 2017 - March 31, 2017), was measured using an interval scale on the motivation of taxpayers in the time period of participation in Tax Amnesty

TABLE 3: Tax Amnesty Participation

\begin{tabular}{|c|c|c|c|c|}
\hline Statement & Code & 1 & 2 & 3 \\
\hline TA & $\begin{array}{l}\text { Participation } \\
\text { Period }\end{array}$ & $\begin{array}{l}\text { Participation } \\
\text { Period I }\end{array}$ & $\begin{array}{l}\text { Participation } \\
\text { Period II }\end{array}$ & $\begin{array}{l}\text { Participation } \\
* \text { Period III }\end{array}$ \\
\hline Category & Score & 3 & 2 & 1 \\
\hline Value & Ranking & $\begin{array}{l}\text { High } \\
\text { Motivation }\end{array}$ & Motivation & $\begin{array}{l}\text { Low } \\
\text { Motivation }\end{array}$ \\
\hline
\end{tabular}

\section{G. Sensitivity test}

This study uses a sensitivity test for corporate tax, ETR, to replace CTTOR as the dependent variable. ETR is an effective tax rate based on applicable financial accounting reporting. Tax expense is a corporate income tax expense for company $i$ in year $t$ based on the company's financial statements. Pretax Income is income before tax for company $\mathrm{i}$ in the year $\mathrm{t}$ based on the company's financial statements

$\mathbf{E T R}=$ Tax $_{\text {Expense }_{i, t}} /$ Pretax $_{\text {Income }_{i, t}}$

\section{H. Control Variables}

\section{1) Financial Conditions}

Interest Coverage Ratio, is the ratio of debt and profitability that is used to determine how easily a company can pay interest on its loans. Rosplock (2001) The measurement scale used by ratios with the formula is as follows:

\section{Interest Coverage $=$ operating income/interest expense}

\section{2) Company Size}

The size of the company shows the size of a company. [29]. To measure a company, natural logarithm (Ln) of total assets is used; with ratio measurement scale.

3) Earning management 
In earnings management it is necessary to do several stages to reflect whether there is earnings management in a company or not. The first step is to look for the total accrual value as a basis for finding the value of discretionary accruals and nondiscretionary accruals. The two values will be compared between the two parameters to find out the dominant value of each company. The earnings management variable uses the modified Jones model approach with the following steps:

$$
\text { DAit }=\left(\frac{T A i t}{A_{i t-1}}\right)-\text { NDAit }
$$

To calculate the total accruals (TAC) of a company in a period can be calculated by the formula [32]

$$
\text { TAit }=\text { NIit }- \text { OCFit }
$$

TAit: Total company accruals i year t;

NIit: Net income (net income) in the company $i$ year $t$; OCFit: Operating cash flow of the company i year $t$.

To estimate total accruals (TAC) with Ordinary Least Square (OLS) to get the regression coefficient can be calculated by the formula [32]:

$$
\frac{T A i t}{A_{i t-1}}=\alpha 1\left(\frac{1}{A_{i t-1}}\right)+\alpha 2\left(\frac{\Delta R E V i t}{A_{i t-1}}\right)+\alpha 3\left(\frac{P P E i t}{A_{i t-1}}\right)+\text { sit }
$$

TAit: Total company accrual in year $\mathrm{t}$;

$\triangle R E V$ it: Net income of company $\mathrm{i}$ year to $\mathrm{t}$ minus net income of year $\mathrm{t}-1$;

$A_{i t-1}$ : Total assets of the company i year $\mathrm{t}-1$;

PPEit: Fixed assets (gross) of the company i year t;

sit: Residual value in company $\mathrm{i}$ year $\mathrm{t}$.

To calculate non-discretionary accruals (NDA), the next step is to regress the first formula so that the values of the coefficients $\alpha 1, \alpha 2$, and $\alpha 3$ are obtained. The coefficient values are then substituted in the following NDA formula [32]:

$$
\text { NDAit }=\alpha 1\left(\frac{1}{A_{i t-1}}\right)+\alpha 2\left(\frac{\Delta R E V i t}{A_{\text {it }-1}}-\frac{\Delta R E C i t}{A_{\text {it }-1}}\right)+\alpha 3\left(\frac{P P E i t}{A_{i t-1}}\right)
$$

NDAit : Non-discretionary accruals (NDA) i year $\mathrm{t}$ $A_{i t-1}$ : Total assets (assets) of the company i year t-1;

$\triangle R E V i t$ : Net income of company i year t minus net income year $\mathrm{t}-1$;

$\triangle R E C$ it: Net accounts receivable for company i year $t$ minus net receivables for year $\mathrm{t}-1$;

PPEit: Fixed assets (gross) of the company i year $\mathrm{t}$.

To calculate discretionary accruals (DA) can be calculated as a measure of earnings management with the formula [31]:

$$
\text { DAit }=\left(\frac{T A i t}{A_{i t-1}}\right)-\text { NDAit }
$$

DAit: Discretionary accruals (DA) i year t;

TAit: Total company accruals i year $\mathrm{t}$;

$A_{i t-1}$ : Total assets (assets) of the company i year t;

NDAit: Non-discretionary accruals (NDA) i year t.

\section{Data Analysis Method}

The method of data analysis uses panel data regression with moderating variables Tax amnesty with the following equation:

Model 1 :

$\mathrm{CTTOR}=\beta_{0}+\beta_{1} \mathrm{KP}+\beta_{2} \mathrm{CG}+\beta_{3} \mathrm{PP}+\beta_{4} \mathrm{KP} * \mathrm{TA}+\beta_{5} \mathrm{CG} * \mathrm{TA}+\beta$ ${ }_{6} \mathrm{PP} * \mathrm{TA}+\beta_{7} \mathrm{KK}_{1}+\beta_{8} \mathrm{UP}+\beta_{9} \mathrm{EM}+\varepsilon_{1}$

Next to the sensitivity test is to replace CTTOR for corporate tax proxy to ETR, so the following equation model is obtained:

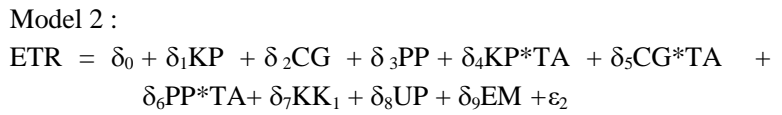

\section{1) Panel Regression Model Estimation}

There are several methods commonly used in estimating the regression model with panel data, namely the fixed effect approach and the random effect approach.

\section{2) Outlier Test}

Outlier testing is carried out if the selected panel model is the Common Effect Model with the aim to detect outlier data that will interfere with research results if not removed. The test uses standardized residuals where the data is said to be outlier if the standardized residual value is greater than absolute 3 .

\section{3) Classical Assumptions}

The classic assumption is made if the model chosen is the Common Effect Model which aims to produce the magnitude of the BLUE (Best Linear Unlimited Estimator) estimation coefficient. The classical assumption testing consists of: normality test, multicollinearity test, heteroskedacity test and autocorrelation test

Panel data is a combination of cross-location data (cross section) and time series data (timeseries). Determination of the best model between the Common Effect, fixed effect, and Random effect using two model estimation techniques. These two techniques are used in panel data regression to obtain an appropriate model in estimating panel data regression. Two tests are used, first the Chow test is used to choose between the Common Effect or fixed effect models. Second, the Hausman test is used to choose the best fixed effect or random effect model in estimating panel data regression.

\section{RESEARCH RESULTS AND ANALYSIS}

\section{A. Descriptive Statistics}

The research population is taxpayers registered in the manufacturing industry which have gone public for the 20142017 period. Then the sample is determined by purposive sampling, with the following criteria.

TABLE 4: Sampling Method

\begin{tabular}{clcc}
\hline \multirow{2}{*}{ No } & \multicolumn{1}{c}{ criteria } & $\begin{array}{c}\text { Number of } \\
\text { Companies }\end{array}$ & $\begin{array}{c}\text { Total data } \\
(2014-2017)\end{array}$ \\
\hline 1 & $\begin{array}{l}\text { The manufacturing } \\
\text { industry goes public } \\
\text { (-) data completeness: }\end{array}$ & 141 & 564 \\
2 & $\begin{array}{l}\text { (-) does not } \\
\text { participate in tax } \\
\text { amnesty }\end{array}$ & 72 & 68 \\
4 & Research sample & 52 & 288 \\
\hline
\end{tabular}


Based on data obtained during the period 2014-2017, the samples obtained were 52 manufacturing industry companies that had sufficient data and who participated in tax amnesty.

Descriptive statistics in this study illustrate corporate tax, market performance, corporate governance and tax amnesty and the results of descriptive statistical processing can be seen in table 5 .

TABLE 5 Statistik Deskriptif

\begin{tabular}{|l|c|c|c|c|}
\hline Variabel & Mean & Std. Dev. & Maximum & Minimum \\
\hline CTTOR & 1.96 & 5.47 & 45.45 & 0.01 \\
\hline ETR & 22.08 & 20.20 & 94.76 & 0.00 \\
\hline KP & 1.54 & 2.05 & 21.57 & 0.05 \\
\hline CG & 48.06 & 16.47 & 69.12 & 3.00 \\
\hline KK & 20.39 & 48.65 & 323.66 & -109.85 \\
\hline UP & 6.001 & 0.56 & 7.67 & 4.59 \\
\hline EM & $-0.14 \mathrm{E}-5$ & 0.10 & 0.36 & -0.55 \\
\hline
\end{tabular}

The results of processing descriptive statistical data can be explained as follows

1. Corporate tax based on the average value of CTTOR shows the amount of $1.96 \%$, this shows the average amount of $\mathrm{PPh}$ owed in a year is relatively small against sales made by manufacturing industry companies listed on the IDX. The greater CTTOR shows the greater proportion of the company's sales proceeds that are used to pay income tax. The standard deviation value of 5.47 shows the variation of CTTOR data between one company and other companies is relatively heterogeneous as the resulting standard deviation exceeds the average value. The maximum value of CTTOR is 45.45 while the minimum value is 0.01 .

2. Corporate tax based on the average ETR value generates a value of $22.08 \%$. The standard deviation value of 20.20 indicates that the variation of ETR data between one company and another company is quite large. The largest value of ETR is 98.76 while the lowest value is 0 .

3. Market performance is indicated by the average value of Tobins' Q, the results of the study indicate that the average value of Tobins.Q is greater than 1 , which is 1.54 so the company has good growth prospects. This illustrates that the company is in over valued condition, where the management is successful in managing the company's assets and the company has the potential for investment growth. A standard deviation of 2.05 indicates that there is a significant variation in market performance between one company and another as shown by the maximum value of 21.57 and the minimum value of 0.05 .

4. Corporate governance produces an average score of $48.06 \%$, which means that the overall implementation of governance in companies engaged in the manufacturing industry is still low. This shows that commitment, transparency, accountability, responsibility, independence, fairness, competence, leadership, ability to work together, vision, mission and values, morals and ethics, as well as strategies in formulating, implementing and evaluating strategies in response to changes in manufacturing industry still relatively low. The standard deviation value of 16.47 indicates a fairly volatile variation between corporate governance of one company and another. The maximum value of corporate ownership is $69.12 \%$ while the minimum value is $3 \%$.
5. The processing results for tax audits show that $70.2 \%$ of tax audits exist for the observation period while $29.8 \%$ did not conduct a tax audit during the observation period.

\begin{tabular}{|l|l|c|c|c|c|}
\multicolumn{2}{|c|}{ TABLE 6: Tax Audit } \\
\hline \multirow{2}{|c|}{} & Frequency & Percent & $\begin{array}{c}\text { Valid } \\
\text { Percent }\end{array}$ & $\begin{array}{c}\text { Cumulative } \\
\text { Percent }\end{array}$ \\
\hline Valid & No audit & 62 & 29.8 & 29.8 & 29.8 \\
\cline { 2 - 6 } & Audit & 146 & 70.2 & 70.2 & 100.0 \\
\cline { 2 - 6 } & Total & 208 & 100.0 & 100.0 & \\
\hline
\end{tabular}

Descriptive statistics for the tax amnesty participation period can be seen in table 4.4. Information from the table shows that there were 19 participants who participated in period 1 with high motivated compliance, while those who participated in period 2 were 27 participants with motivated compliance, while those who participated in the third period were 6 participants with motivated compliance low. The results showed that the manufacturing industry is in a level of compliance that meets Law 11/2016 on Tax Amnesty.

TABLE 7: Tax Amnesty Participation Period

\begin{tabular}{|c|c|c|c|}
\hline Periode tax amnesty & $\mathbf{1}$ & $\mathbf{2}$ & $\mathbf{3}$ \\
\hline Score & 3 & 2 & 1 \\
\hline Compliance Rating & $\begin{array}{c}\text { High } \\
\text { Motivation }\end{array}$ & Motivation & $\begin{array}{c}\text { Low } \\
\text { Motivation }\end{array}$ \\
\hline $\begin{array}{c}\text { TA participants (2016- } \\
\text { 2017 period) }\end{array}$ & 19 & 27 & 6 \\
\hline
\end{tabular}

B. Effects of Market Performance, Corporate Governance and Tax Examination on CTTOR with Tax amnesty as a moderating variable

This study examines the effect of market performance, corporate governance and tax audits on CTTOR with tax amnesty as a moderating variable using panel data models.

1. Classic assumption test

TABLE 8: Classic assumption test

\begin{tabular}{|c|c|c|}
\hline \multicolumn{3}{|c|}{ Kolmogorov Smirnov (KS) Test Normality Test } \\
\hline & \multicolumn{2}{|c|}{ Unstandardized Residual } \\
\hline $\mathrm{N}$ & \multicolumn{2}{|c|}{216} \\
\hline Kolmogorov-Smirnov Z & \multicolumn{2}{|l|}{1,092} \\
\hline Asymp. Sig. (2-tailed) & \multicolumn{2}{|l|}{, 159} \\
\hline \multicolumn{3}{|c|}{ Multicollinearity Test } \\
\hline & \multicolumn{2}{|l|}{ Collinearity Statistics } \\
\hline & Tolerance & VIF \\
\hline KP & ,398 & 2,513 \\
\hline CG & ,890 & 1,123 \\
\hline PP & 689 & 1,452 \\
\hline $\mathrm{Kk}$ & ,932 & 1,073 \\
\hline UP & 452 & 2,212 \\
\hline ML & ,911 & 1,098 \\
\hline KPTA &, 140 & 7,129 \\
\hline CGTA &, 152 & 6,565 \\
\hline PPTA & 281 & 3,553 \\
\hline \multicolumn{3}{|c|}{ 1) Glejser test heteroscedasticity Test } \\
\hline Model & \multicolumn{2}{|l|}{ Sig. } \\
\hline KP & &, 860 \\
\hline $\mathrm{CG}$ & & ,207 \\
\hline PP & & ,940 \\
\hline $\mathrm{Kk}$ & & ,696 \\
\hline UP & &, 111 \\
\hline ML & &, 503 \\
\hline KPTA & &, 178 \\
\hline CGTA & &, 195 \\
\hline PPTA & &, 384 \\
\hline \multicolumn{3}{|c|}{ Watson durbin autocorrelation test } \\
\hline Model & Sig. & \\
\hline DW & & 2,090 \\
\hline DU & & 1,863 \\
\hline DL & & 1,675 \\
\hline
\end{tabular}


The normality test results are known to be Asymp values. Sig (2 tailed) is. 159, which means greater than 0.05. In accordance with the provisions of the K-S test if the sig value is greater than 0.05 then the data distribution is normal. So that research in the regression model can be continued.

Based on the results of multicollinearity tests that have been done on the research model showing the CTTOR variable, the table above shows that the VIF value is in accordance with the stipulation, which must be less than 10 and the tolerance value must be greater than 0.1 , so the above table shows that there is no correlation between the dependent variables, so it can be declared free from multicollinearity.

In this test using Glejser statistical Test, that if the value of sig $>0.05$, it can be said that heteroscedasticity does not occur, and vice versa. The test results in the table above show that the sig value is greater than 0.05 , it can be concluded that in this regression model no heterokesdastity problems were found.

To find out whether or not there is autocorrelation, the Durbin Watson test (DW test) is used with the following conditions DU <DW <4-DU, then there is no autocorrelation. The results showed the DW was 2.09, the DU value was 1.863 and the DL value was 1.675. This shows that autocorrelation did not occur.

\section{Model Estimation Test}

TABLE 9: Model Estimation Test

\begin{tabular}{|c|c|}
\hline \multicolumn{2}{|c|}{ Test Model Chow Test Result } \\
\hline Effects test & Prob \\
\hline Cross-section $\mathrm{F}$ & 0.000 \\
\hline $\begin{array}{c}\text { Cross-section Chi- } \\
\text { square }\end{array}$ & 0.000 \\
\hline \multicolumn{2}{|c|}{ Test Model Hausman Test Result } \\
\hline \multicolumn{2}{|c|}{ Test Summary } \\
\hline $\begin{array}{c}\text { Cross-section } \\
\text { Random }\end{array}$ \\
\hline
\end{tabular}

For Cross-section F compared with the value of Prob. with $\alpha(0.05)$, showing the value of Prob. $<\alpha$ that is equal to 0,000 $<0.05$, it can be concluded based on the Chow Test, the Fixed Effect model is more appropriate than the Common Effect model

To choose one of the approaches used is a fixed effect or Random effect. In this research, the random effect is used because the probability is more than 0.05

3. Regression Test Model Random effect

TABLE 10: Regression Test Model Random effect Model I $=$ CTTOR : $\alpha_{0}+\sigma_{1} \mathrm{KP}+\sigma_{2} \mathrm{CG}+\sigma_{3} \mathrm{PP}+\sigma_{4} \mathrm{KP} * \mathrm{TA}+\sigma_{5} \mathrm{CG} \mathrm{TA}^{*}$ $+\sigma_{6} \mathrm{PP} * \mathrm{TA}+\sigma_{7} \mathrm{KK}_{1}+\sigma_{8} \mathrm{UP}+\sigma_{9} \mathrm{ML}+\varepsilon$

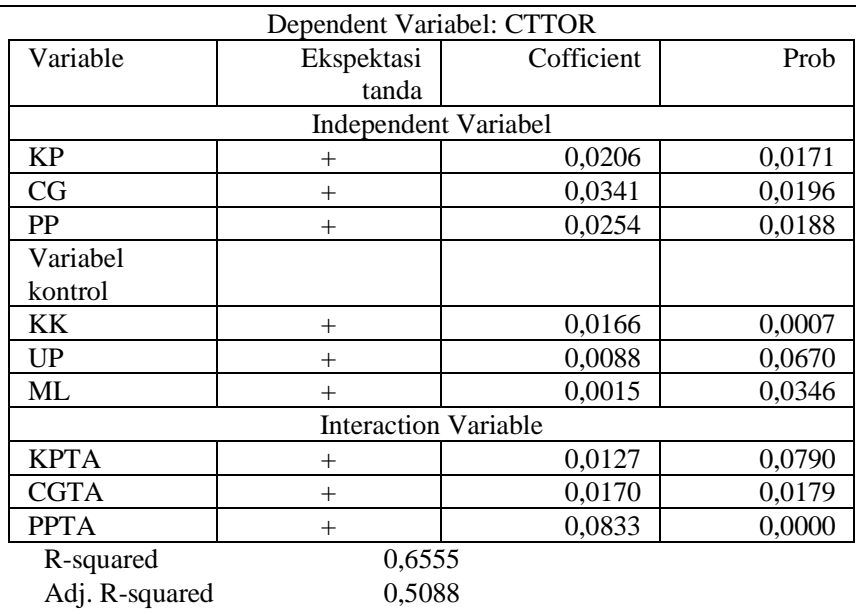

F-statistic $\quad 3,2130$

Prob F-stat $\quad 0,0288$

Table description: This table presents the estimation of the second main research model using the multiple regression method with panel data using the Random Effect model. The dependent variable is CTTOR. The independent variables include market performance (KP) with Tobins Q proxy, corporate governance (CG) with ACGS index proxy and tax audit (PP). The control variable is the financial condition (KK), with an interest coverage proxy, company size (UP) with a log total asset proxy, earnings management (ML). Interaction variables are KPTA, CGTA and PPTA

The results showed that:

1. Based on the $\mathrm{F}$ stat test shows that corporate governance, market performance and tax audits jointly influence the CTTOR because the F stat probability (0.029) is less than $5 \%$.

2. Based on the coefficient of determination shows that CTTOR can be explained by market performance, corporate governance and tax auditing by 65 percent while the rest is explained by other variables not included in the model.

3. Based on the $\mathrm{t}$ stat test shows that market performance has a positive effect on CTTOR of 0.0206 because the probability stat $t$ of 0.0171 is less than $5 \%$, so hypothesis 1 is accepted.

4. Based on the $t$ stat test shows that corporate governance has a positive effect on CTTOR of 0.0341 because the probability stat $\mathrm{t} 0.0196$ is less than $5 \%$ so hypothesis 2 is accepted.

5. Based on the $t$ stat test shows that the tax audit has a positive effect on CTTOR 0.0254 because the $t$ stat probability 0.0188 is less than $5 \%$ so hypothesis 3 is accepted.

6. Based on the $\mathrm{t}$ stat test shows the tax amnesty strengthens the influence of market performance on CTTOR by 0.0127 because the probability stat $t 0.0790$ is less than $5 \%$ so hypothesis 4 is accepted.

7. Based on the $\mathrm{t}$ stat test shows the tax amnesty strengthens the influence of corporate governance on CTTOR by 0.0170 because the probability stat $\mathrm{t} 0.0179$ is less than $5 \%$ so hypothesis 5 is accepted.

8. Based on the $t$ stat test shows the moderation of tax amnesty is to strengthen the effect of tax audits and CTTOR of 0.08330 .0342 because the probability of $t$ stat 0.0670 is less than $5 \%$ so that hypothesis 6 is accepted.

\section{Interpretation of Research Results}

Based on the $\mathrm{t}$ stat test shows that market performance has a positive effect on CTTOR so that hypothesis 1 is accepted, the greater the market performance, the corporation tax will also increase. this proves that the higher the market performance, the corporation tax will also increase. This study supports the opinions of [6]-[8], [33].

This study is in accordance with the opinion of [6] that analyzes the role of financial market performance to generate tax revenue in Pakistan. The results showed that the number of bank branches and market capitalization had a positive and significant impact on tax revenues, so that as market performance improved, corporate taxes would be higher as well; [7], The results of the study show that there is a unidirectional causal relationship from the capital market to tax revenue, so that the increase in market performance, corporate tax will be higher too; [4], the results of the study show that the stock market performance significantly influences the government tax revenue and the development of the stock market and economic growth affects the income 
tax, so that the market performance increases, corporate tax will also be higher; [8], the results of the study showed that the stock market performance gave the largest contribution to changes in corporate tax revenue, so that the increase in market performance would also be higher corporate taxes; Ilievski, (2015) ,. The results showed that the stock market is a part in collecting tax revenues and market performance has a positive effect on increasing tax revenue, so that the increase in market performance, corporate tax will be higher too

\section{The effect of GCG on corporate tax (CTTOR)}

The results showed that corporate governance has a positive effect on CTTOR so that hypothesis 2 is accepted, this result indicates that the higher the application of corporate governance, the corporate tax will increase. The results of this study support the opinions of [14]-[17].

This study supports the opinion of [15] taxation has significant implications for improving governance problems, the results of the study show that the tax effect on debt and corporate payment policies are enriched by including governance considerations and managerial compensation, so that corporate governance will affect tax corporation

This study supports the opinion of [16] analyzing significant differences in the level of corporate tax compliance among Malaysian public companies before and after the revision of MCCG. The results showed that the function of the Board and Audit Committee in improving corporate governance practices has a significant impact on the level of corporate tax compliance, directors' ownership has a significant negative relationship with the level of corporate tax compliance, corporate tax compliance is higher if the chairman of the Audit Committee has a background accounting or audit education or practical experience, the activities of the Audit Committee (meetings) have brought good signals and have an impact on corporate governance performance, especially in monitoring corporate tax compliance, company size and corporate leverage have a negative relationship with the level of corporate tax compliance, so corporate governance will affect corporate tax. Likewise, with the opinion of [14] The results of the study indicate that the corporate governance system influences the level and sensitivity of tax revenue to tax changes, [17] the function of transparency in governance in taxation,

\section{Effect of tax audits on corporate tax (CTTOR)}

Based on the $t$ stat test, the tax audit has a positive effect on CTTOR, the results of the study indicate that the tax audit has a positive effect on corporate tax. The results of this study support the opinions of [18], [19].

Taxpayer compliance is the main factor affecting tax revenue realization. According to [1] "The size of the tax gap reflects the level of tax compliance. According to Setiana et al. (2010) many attempts were made by DGT in increasing tax payment receipts. Tax Audit is an examination carried out to test the compliance of the implementation of a regulation (compliance audit). In the Tax Audit, the examiner must hold on supporting evidence of events or transactions that occur. So that the tax calculation as presented in the SPT must be supported with proper and adequate documents. Considering this supporting evidence is very important for the examiner (fiskus) in carrying out the examination, the system and administration of bookkeeping or recording, and the archiving of supporting documents by the Taxpayer plays a very large role.

Based on the self-assessment system, taxpayers calculate, pay and report their tax obligations. As a logical consequence of the system, the Directorate General of Taxes conduct audits with the main objective of testing compliance with taxation obligations in order to improve taxpayer compliance. For this reason, the examination will be carried out continuously by improving the quality of the existing examination and examiners, accompanied by improvements to the applicable provisions. Taxpayers themselves are required to have active, positive and constructive participation so that the audit can be carried out effectively. With the Tax Examination, it is possible to obtain feedback in order to increase his understanding of the application of the correct tax regulations, which in turn will increase his awareness to fulfill his tax obligations. Examination without the support of the taxpayer will be more wasting resources on the tax administration.

This study supports the opinion of [19] exploring the factors that influence the effectiveness of tax audits in Tanzania. The results showed that based on four categories: related to the organization, related to tax auditors, related to taxpayers and factors related to regulation. Research findings indicate that there are five main important factors for the effectiveness of tax audits; The first factor, which is the implementation of the tax auditor's recommendations by management, is found under the organizational category; The second factor, namely the adequacy of the tax audit unit, is found under the tax auditor category; The third factor is the attitude of taxpayers, found under the category of taxpayers; The fourth and fifth factors, namely the availability and implementation of regulations and pajakaudit standards, and the leadership and tax policies for tax audits, respectively, are found under the regulatory category, so corporate tax will increase. So is the opinion of [18]. The results of the study show that tax auditors can track tax violations correctly. [27], Researching the impact of tax audits on voluntary compliance. Likewise [28], The results show that the use of information system tools can enable tax auditors to track tax violations, thereby contributing to the effectiveness of increasing tax audits.

7. Tax amnesty strengthens the effect of market performance on corporate tax

The results showed that the interaction between market performance and corporate tax is positive, this shows that tax amnesty can strengthen the relationship between market performance and corporate tax. This research supports opinion. Market performance is a critical factor for the survival of companies, thus affecting corporate taxes. [4] shows that government tax revenue depends on the company's market performance. This is supported by [6], [34], [8] and [9]

Research [21] and [22] have proven that tax amnesty will increase corporation tax. Various benefits of the Tax Amnesty mentioned above can be concluded that the tax burden to be borne by the company will be much lighter and this will indirectly ease the company's financial burden and ultimately help improve company performance. The effect of tax amnesty on corporate tax is supported by [23]-[26] which 
analyzes whether tax amnesty is a good policy and tax amnesty will increase short-term income.

The results of this study prove that moderating tax amnesty can strengthen the effect of market performance on corporate tax.

8. Tax amnesty strengthens the influence of corporate governance on corporate tax

The results showed that positive tax amnesty strengthens the influence of corporate governance and corporate tax. The results of this study support the effect of corporate governance on corporate taxation, among others, conducted by [14]-[17] that the impact of effective corporate governance will have a positive effect on corporate taxation the impact of effective corporate governance will have a positive effect on corporate taxation.

Companies that implement Tax amnesty for assets and liabilities that have not been reported will increase investor confidence in transparency and accountability. This is because the more transparent and accountable a company is, the higher the level of public trust in the company's financial statement information, so that people's interest in investing their funds in the company will be higher. This can be seen in the expectation of high future cash flow and high profitability. With the high profitability generated by the company, tax revenues will rise. Research [21] and [22] have proven that tax amnesty will increase corporate taxation and this study also supports [24] research, the function of tax amnesty in addressing tax evasion in Nigeria The function of tax amnesy is increasing government revenue to meet daunting challenges in facing slow growth in trade and investment, and also supported by [23], [25], [26].

Benefits Tax amnesty is a rule made by a country's tax authority to provide opportunities for taxpayers who are not compliant, report their income and pay taxes voluntarily by providing incentives to them. In the short term, tax amnesty aims to increase state revenue, whereas in the long run it aims to increase taxpayer compliance

So based on this research shows that with the tax amnesty can strengthen the relationship between corporate gorvenance and corporate tax performance

9. Tax amnesty strengthens the effect of tax audits on corporate tax

The results showed that tax amnesty moderation can strengthen the effect of tax audits on corporate tax so that it is called pure moderation.

Taxpayer compliance is the main factor affecting tax revenue realization. According to [1] "The size of the tax gap reflects the level of tax compliance. According to Setiana et al. (2010) many attempts were made by DGT in increasing tax payment receipts. One of the steps taken is to improve the audit function which includes tax service and tax law enforcement, both of which significantly affect the compliance of taxpayers' payments. To increase tax payments, the audit function of the DGT must be able to overcome various problems that have been affecting tax revenue. Among them are handling the problem of unregistered taxpayers, taxpayers who do not submit tax returns, tax smugglers and tax arrears. In addition, to increase tax revenue in Indonesia, the government needs to take steps to reform taxation, which is one of the important aspects that needs to be addressed. The researchers managed to obtain empirical evidence that tax control affects corporate taxes, such as [18], [19].

The results showed that tax amnesty strengthens the effect of tax audits and corporate performance, this is because this study supports the opinion of [21] the Tax amnesty program organized by the Turkish government resulted in reduced workload of administrators, tax court bodies and increased tax revenue efficiency. This happens because the participants of the Tax Amnesty have submitted the letter of ownership of the assets along with the attached evidence, making it easier for administrators to supervise and verify the assets of the Taxpayer.

This research shows that the existence of tax amnesty shows that the higher taxpayer compliance in fulfilling its tax obligations, it will be followed by an increase in the receipt of Corporate Taxpayer Income Tax at the Tax Service Office and corporate tax. This proves that the existence of tax amnesty provides a positive influence between tax audits and corporate tax.

C. Sensitivity Test Effect of Market Performance, Corporate Governance and Tax Examination of ETR with Tax Amnesty As a Moderating variable

This study examines the sensitivity of the effect of market performance, corporate governance and tax audits on ETR and tax amnesty as moderating variables using panel data models

\section{1) Classic assumption test}

TABLE 11: Classic assumption test Model II

Uji Sensitivitas Normalitas One-Sample Kolmogorov-Smirnov Test

\begin{tabular}{|l|r|}
\hline & Unstandardized Residual \\
\hline $\mathrm{N}$ & 216 \\
Kolmogorov-Smirnov Z & 1,092 \\
Asymp. Sig. (2-tailed) &, 259 \\
\hline
\end{tabular}

Uji Sensitivitas heteroskedasitas glejser

\begin{tabular}{|l|r|}
\hline Model & \multicolumn{2}{|c|}{ Sig. } \\
\hline KP & \\
CG &, 495 \\
PP &, 973 \\
KK &, 903 \\
UP &, 608 \\
ML &, 511 \\
KPTA &, 914 \\
CGTA &, 128 \\
PPTA &, 229 \\
\hline &, 768 \\
\hline
\end{tabular}

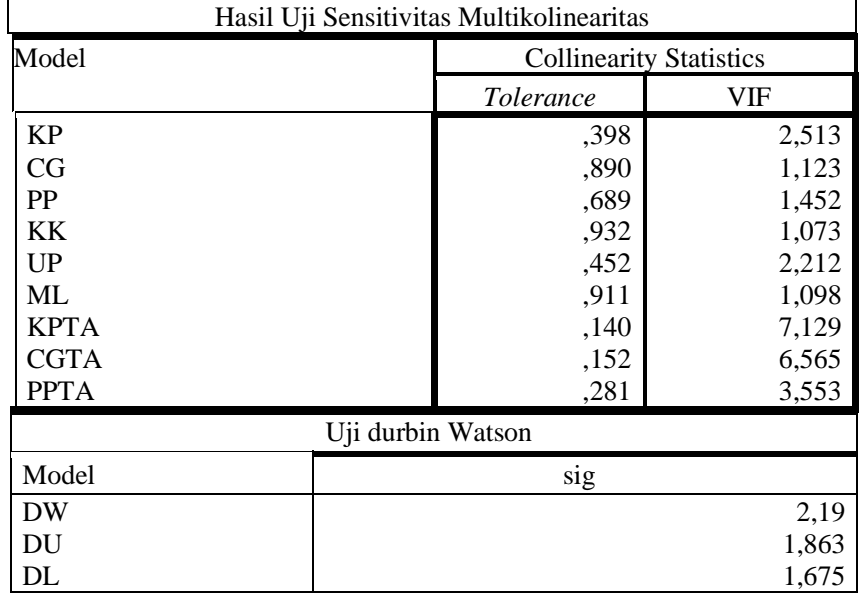

The normality test results are known to be Asymp values. Sig (2 tailed) is .259, which means greater than 0.05. In 
accordance with the provisions of the K-S test if the sig value is greater than 0.05 then the data distribution is normal. So that research in the regression model can be continued.

Heteroskedacity test, this test uses a glacier statistical test, with the proviso that if the sig value $>0.05$, it can be said that there is no heteroscedacity, and vice versa. The test results in the table above show that the sig value is greater than 0.05 , it can be concluded that in this regression model no heterokesdastity problems were found.

Based on the multicollinearity test results that have been carried out on the research model shows the variable corporate performance, the table above shows that the VIF value is in accordance with the stipulation, which must be less than 10 and the tolerance value must be greater than 0.1 , so the above table shows that there is no correlation between the dependent variables, so that it can be declared free from multicollinearity.

To find out the presence or absence of autocorrelation, the Durbin Watson test (DW test) is used with the following conditions DU <DW <4-DL, then there is no autocorrelation. The results showed the DW was 2.13, the DU value was 1.863 and the DL value was 1.675 . This shows that autocorrelation did not occur.

\section{2) Model Estimation Sensitivity Test}

TABLE 12: Uji Model II

\begin{tabular}{|l|r|}
\hline \multicolumn{2}{|c|}{ Hasil Uji Sensitivitas Chow Test } \\
\hline Effects test & Prob \\
\hline Cross-section $\mathrm{F}$ & \\
\hline Cross-section Chi-square & 0.000 \\
\hline \multicolumn{1}{|c|}{ Hasil Uji Sensitivitas Hausman } \\
\hline Test Summary & Prob. \\
\hline \hline Cross-section Random & \\
\hline
\end{tabular}

For Cross-section F compared with the value of Prob. with $\alpha(0.05)$, showing the Prob value. $<\alpha$ that is equal to 0,000 $<0.05$, it can be concluded based on the Chow Test, the Fixed Effect model is more appropriate than the Common Effect model

To choose one of the approaches used is a fixed effect or random effect with a probability greater than 0.05 then using the random effect

\section{3) Model IV Sensitivity Regression Test (ETR)}

This hypothesis test is to analyze the effect of market performance, corporate governance and tax audits on corporate taxes with ETR and tax amnesty proxies as moderating variables.

The results showed that:

1. The coefficient of determination is 0.641 , this shows that the ETR model can be explained by the independent variable at $64.1 \%$, while the rest is explained by other variables not included in the model.

2. The probability value of $\mathrm{F}$ stat is less than $5 \%$, this shows that all independent variables together influence the ETR.

3. Market performance has no effect on ETR with a $95 \%$ confidence level but has a negative effect on a $90 \%$ confidence level of -0.0528 .
4. Corporate governance has a positive effect on ETR at a $95 \%$ confidence level of 0.255 .

5. The tax audit has a positive effect on ETR at the $95 \%$ confidence level of 0.06 .

6. Tax amnesty weakens the market performance of ETRs at a $90 \%$ confidence level of -0.0313 .

7. Tax amnesty strengthens corporate governance towards ETR at $95 \%$ confidence level of 0.06 .

8. Tax amnesty strengthens the tax audit of ETR at a $95 \%$ confidence level of 0.06 .

TABLE 13: Model II Sensitivity Regression Test

\begin{tabular}{|c|c|c|c|}
\hline \multirow{2}{*}{\multicolumn{4}{|c|}{$\begin{array}{c}\text { Model } 4=\text { ETR: } \alpha_{0}+\xi_{1} \mathrm{KP}+\xi_{2} \mathrm{CG}+\xi_{3} \mathrm{PP}+\xi_{4} \mathrm{KP} * \mathrm{TA} \\
+\xi_{6} \mathrm{PP} * \mathrm{TA}+\xi_{7} \mathrm{KK}_{1}+\xi_{8} \mathrm{UP}+\xi_{9} \mathrm{ML}+\varepsilon \\
\text { Variabel Terikat }: \text { ETR }\end{array}$}} \\
\hline & & & \\
\hline Variable & $\begin{array}{c}\text { Ekspektasi } \\
\text { tanda }\end{array}$ & Cofficient & Prob \\
\hline \multicolumn{4}{|c|}{ Variabel bebas } \\
\hline KP & + & $-0,0528$ & 0,0894 \\
\hline $\mathrm{CG}$ & + & 0,2559 & $0,0437 * *$ \\
\hline PP & + & 0,0608 & $0,0385 * *$ \\
\hline \multicolumn{4}{|c|}{ Variabel kontrol } \\
\hline KK & + & $-0,1701$ & 0,0644 \\
\hline UP & + & $-1,9864$ & $0,0135 * *$ \\
\hline $\mathrm{ML}$ & + & 0,0195 & $0,0404 * *$ \\
\hline \multicolumn{4}{|c|}{ Variabel interaksi } \\
\hline KPTA & + & $-0,0313$ & 0,0060 \\
\hline CGTA & + & 0,0606 & $0,0390 * *$ \\
\hline PPTA & + & 0,0604 & 0,0064 \\
\hline
\end{tabular}

Table description: This table presents the estimated model with the multiple regression method with panel data using the RandomEffect model. The dependent variable is ETR. The independent variables include market performance (KP) with Tobins Q proxy, corporate governance (CG) with corporate governance index proxy and tax audit (PP). The control variable is the financial condition (KK), with an interest coverage proxy, company size (UP) with a log total asset proxy, earnings management (ML). Interaction variables are KPTA, CGTA and PPTA.

\section{4) Interpretation of research results}

This study compares the effect of market performance, corporate governance and tax audits on corporate taxes with the ETR tax amnesty proxy as a moderating variable. Basically CTTOR is used as a measure of corporate tax, because CTTOR is one of the levels of profit and company inputs that are carried out benchmarking, namely the ratio between income tax payable to sales as stipulated in SE Director General of Tax no SE 96 / PJ / 2009 concerning the ratio total benchmarking and CTTOR take into account both positive and negative fiscal corrections, and both of these are not included in the ETR measurement.

The sensitivity test found inconsistent evidence regarding the effect of market performance on corporate tax after replacing CTTOR with ETR. The results of the model I study which originally showed that market performance influences corporate tax by using the CTTOR proxy, in model II the ETR proxy is used with the results showing market performance has no effect on corporate tax, so the sensitivity test is rejected, this is because the market performance testing will affect the CTTOR derived from tax costs compared to sales which take into account market performance, so that the ETR has no effect, because ETR is derived from tax costs compared to profits which only take into account financial performance. 
Sensitivity testing shows that corporate governance will affect corporate tax both measured by CTTOR in model I and by ETR in model II, this shows that the higher the corporate governance index, the higher ETR will be.

The sensitivity test found consistent evidence of the effect of a tax audit on corporate tax after replacing CTTOR with ETR. The results of model I research that originally showed that tax audits affect corporate tax by using the CTTOR proxy as well as ETR show that tax audits affect corporate taxes.

The results of the study the effect of tax audits on CTTOR in model I and ETR in model II show consistent evidence that is a positive effect on market performance.

The results showed inconsistent evidence that the influence of tax amnesty strengthens the effect of market performance on CTTOR in model I compared to tax amnesty reinforces the effect of market performance on ETR in model II, which was positive to no effect, this is because basically CTTOR used as a tool measuring corporate performance, because CTTOR is one of the levels of profit and company inputs that is carried out benchmarking, namely the ratio between income tax payable to sales as stipulated in SE Director General of Taxes no SE 96 / PJ / 2009 concerning the ratio of total benchmarking and CTTOR taking into account fiscal correction both positive and negative, and both of these are not included in the ETR measurement.

Sensitivity testing found consistent evidence of the effect of tax amnesty strengthening the effect of corporate governance on corporate tax after replacing CTTOR in model I with ETR in model II. The results showed that tax amnesty would strengthen the effect of corporate governance on corporate tax both with CTTOR and ETR.

Sensitivity testing found consistent evidence of the effect of tax amnesty strengthening the effect of tax audits on corporate tax after replacing CTTOR in model I with ETR model II. The results showed that tax amnesty would strengthen the effect of corporate governance on corporate tax both with CTTOR on model I and ETR on model II.

Based on the results of research conducted in model II compared to model I it is found that there are different market performance variables results between testing in model I and model II. The difference in research results between model I and model II encourages researchers to conduct sensitivity tests on the dependent variable that exists that is, corporate tax as measured by CTTOR in model I and ETR model II.

\section{CONCLUSIONS AND IMPLICATIONS}

\section{A. Conclusions}

1. Market performance has a positive effect on corporate taxes, this shows that the higher the market performance as measured by tobin $\mathrm{Q}$, the corporation tax increases.

2. Corporate governance has a positive effect on corporate tax, this shows that the higher the index of corporate governance, corporate tax increases.

3. Tax audits have a positive effect on corporate taxes, this shows that the higher the inspection of taxes carried out, the corporation tax will increase.

4. Tax amnesty strengthens the positive influence of market performance and corporate tax, because tax amnesty has a positive influence on market performance and corporate tax with pure moderation.

5. Tax amnesty strengthens the positive influence of corporate governance and corporate tax, so that with the tax amnesty the positive effect on corporate governance and corporate tax will increase with the type of pure moderation.

6. Tax amnesty strengthens the positive effect of tax audits and corporate tax, because tax amnesty has a positive influence on the relationship between tax audits and corporate tax with pure moderation.

\section{B. Interpretation of Research Results}

1. Practical implications. The findings of this study can be used by the tax authorities to increase corporate taxation by paying attention to market performance, and taxpayer governance, while improving tax audits carried out; For companies to be used as input and consideration in perfecting tax management strategies that can help to be more effective and efficient in making organizational decisions to obtain maximum corporate tax. This includes tax planning (Tax Planning) implementation of tax obligations (tax Implementation) and tax control (Tax Control).

2. Theoretical implications. Enriching the taxation literature with the finding that the presence of tax amnesty can strengthen the influence of market performance, governance and tax audits of corporate taxes. For theories about tax science, this research can be used as a basis for decision making or further reference, provide a basic understanding of the importance of tax management for companies, apply tax management in companies, provide problem solving skills in tax problems in companies.

3. Policy implications. Give input to regulators, both the government and the House of Representatives, to pay attention to corporate governance of taxpayers and Tax amnesty in the preparation of regulations / laws. Tax amnesty can function to: Eliminate taxes on newly reported assets, Eliminate administrative sanctions and tax criminal sanctions, Not subject to tax inspection and investigation, Stop the tax inspection and investigation process, Your tax amnesty data will be kept confidential, Waiver of income tax on additional assets that will be reversed name, Make it easy for taxpayers to access banking services. Furthermore, the implications for the Government especially the Financial Services Authority (OJK) as input in evaluating regulations on financial reporting related to taxation and for the Director General of tax can be used as input material to understand the behavior of corporate taxpayers and show that clear regulations and strong law enforcement affect towards taxpayer behavior.

\section{REFERENCE}

[1] Gunadi. (2016). Panduan Komprehensif Pajak Penghasilan. Jakarta BEE Media Indonesia. Handoko, Yunus. (2014) Implementasi Social and Environmental Disclosure dalam Perspektif Teoritis Jurnal JIBEKA,Vol.8 No.2

[2] Meilinda, Maria (2013) Pengaruh Corporate Governance Terhadap Manajemen Pajak, Diponegoro Journal of Accounting, Volume 2, Nomor 3.

[3] Wulandari, May dan Dovi Septiari. (2016). Effective Tax Rate : Efek dari Corporate Goverance. Jurnal Akuntansi.

[4] Plíhal, T., \& Urbanovský, T. (2017). Increasing Impact Of Stock Market Performance On Government Tax Revenues. KnE Social Sciences, 1(2), 333. https://doi.org/10.18502/kss.v1i2.667 Purwono, 
Herry. (2010). Dasar-Dasar Perpajakan \& Akuntansi Pajak. Jakarta: Penerbit Erlangga, 2010.

[5] Fadila \& Handayani, Rr Sri. (2019), Tax Amnesty Effect On Tax Avoidance And Its Consequences On Firm Value (Empirical Study On Companies In Indonesia Stock Exchange), Jurnal Dinamika Akuntansi Vol 11, No 5.

[6] Akram, N. (2016). Do Financial Sector Activities Affect Tax Revenue in Pakistan? 2(Winter), 153-169.

[7] Javaid, Muhammad Irfan, Roshaiza Taha, Muhammad Imran Farooq (2014). Tax Revenue, Stock Market and Economic Growth of Pakistan, Acta Universitatis Danubius Vol.10, No.5.

[8] Taha, R. (2013). Stock Market and Tax Revenue Collection in Malaysia: Evidence From Cointegration. 5(1), 29-40.

[9] Ilevski, B. (2015). Stock Markets and Tax Revenue. Acta Universitatis Danubius Economica, 10(5), 136-148.

[10] Schofield Max (2015) Corporate Governance and Tax: Stonger Together Working Paper No.01/2015.

[11] FCGI. (2001). Corporate Governance; Tata Kelola Perusahaan. Jakarta.

[12] Aprilia, A. (2014). Penanganan Dan Pengawasan Perpajakan Dalam Rangka Intensifikasi Di Bidang E-Commerce (Studi Pada Kantor Pelayanan Pajak Pratama Malang Selatan). Jurnal Mahasiswa Perpajakan. Vol.2. No.1, 1- 10.

[13] Johnson, E., Maciejovsky, B., and Schneider, F. (2014). Everyday Representations of Tax Avoidance, Tax Evasion, and Tax Flight: Do Legal Differences Matter? Journal of Economic Psychology, 24(4):535- 553.

[14] Desai, Mihir, Alexander Dyck,Luigi Zingales. (2003). Corporate Governance and Taxation and Working paper,. [J]. Harvard University and NBER.

[15] Desai (2007). Taxation and Corporate Governance: An Economic Approach. Ssrn, 383. https://doi.org/10.2139/ssrn.983563 133.

[16] Samsuddin Mohd. Amin, Rohaya Md. Noor, Nor'azam Mastuki \& Abdul Rauf Ambali. (2011). Corporate Governance and Tax Compliance, Engineering and Industrial Applications (ISBEIA), IEEE Symposium on Business.

[17] Friese, A., Link, S., \& Mayer, S. (2008). Taxation and Corporate Governance - The State of the Art. Tax and Corporate Governance, 357-425. https://doi.org/10.1007/978-3-540-77276-7_25.

[18] Olaoye, Clement Olatunji dan Ogundipe, Ayobolawole Adewale. (2018). Application of Tax Audit and Investigation on Tax Evasion Control in Nigeria Journal of Accounting, Finance and Auditing Studies 4/1 (2018) 79-92 137.

[19] Chalu, H., \& Mzee, H. (2018). Determinants of tax audit effectiveness in Tanzania. Managerial Auditing Journal, 33(1), 35-63. https://doi.org/10.1108/MAJ-06-2016-1390.

[20] Rinaldi. (2017). Dampak Tax amnesty Terhadap Laporan Keuangan Dan Pengaruhnya Kepada Nilai Perusahaan. Jurnal Adhum, VII(1), 33-43. Rosplock, M.F. (2001). Advanced Analytical Techniques for Performing Forensic Financial Analysis, Business Credit; 103, hal 6.

[21] Fatih, Saracoglu Osman dan Eren Caskurlu. (2011). Tax amnesty with Effects and Effecting Aspects: Tax Compliance, Tax Audits and Enforcements Around; The Turkish Case. International Journal of Business and Social Science, Vol.2 No.7.

[22] Nar. (2015). The Effects of Behavioral Economics on Tax amnesty, The International Journal of Business in Society. Emerald Insight.

[23] Alm, J., Martinez-Vazquez, J., \& Wallace, S. (2009). Do Tax Amnesties Work? The Revenue Effects of Tax Amnesties During the Transition in the Russian Federation. Economic Analysis and Policy, 39(2), 235-253. https://doi.org/10.1016/S0313-5926(09)50019-7.

[24] Agbonika, J. (2015). Tax Amnesty For Delinquent Taxpayers: A Cliché In Nigeria, Global Journal of Politics and Law Research Vol.3, No.3, 105- 120.

[25] Mikesell, J. L., \& Ross, J. M. (2012). Amnesties To Public Revenue Systems, 65(September), 529-562.

[26] Luitel, H.S. (2014). Is tax amnesty a good policy? London: Lexington Books.

[27] Niu, Yongzhi. (2010). Tax audit impact on voluntary compliance. Mp r a. (7326)

[28] Drogalas, George , Sorros Ioannis, Karagiorgou Dimitra, and Diavastis Ioannis. (2015). Tax audit effectiveness in Greek firms: Tax auditors'perceptions, Journal of Accounting and Taxation, Vol. 7(7), 123-130.

[29] Dewi, Ayu Sri Mahatma dan Wiratma, Ary. (2016). Pengaruh Struktur Modal, Profitabilitas Dan Ukuran Perusahaan Pada Nilai Perusahaan, E-Jurnal Akuntansi.

[30] Rahadian. (2008). Memahami konsep tata kelola perusahaan yang sehat. Retrieved July 23, 2017, from http://portal.kopertis3.or.id.

[31] Zulkarnaen, N. (2015). Pengaruh Good Corporate governance Terhadap Manajemen Pajak. Jurnal Bisnis Dan Manajemen, 5(1).
[32] Felicia\&Meiden (2016). Perbandingan KInerja Perusahaan dan Manajemen Laba Pada Perusahaan Yang Melakukan Merger dan Akuisisi, Jurnal Akuntansi, Vol 5 No 2.

[33] Ilevski, B. (2015). Stock Markets and Tax Revenue. 5(3), 1-16. Irfan Javaid Attari, M., Taha, R., \& Imran Farooq, M. (2014). Tax Revenue, Stock Market and Economic Growth of Pakistan. Acta Universitatis Danubius (Economica, 10(5), 136-148.

[34] Attari, M., Taha, R., \& Imran Farooq, M. (2014). Tax Revenue, Stock Market and Economic Growth of Pakistan. Acta Universitatis Danubius Economica, 10(5), 136-148.

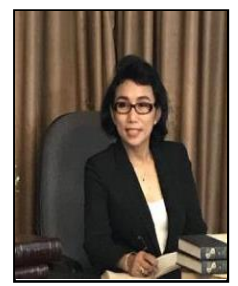

Dr. Agoestina Mappadang, SE.Ak., MM., BKP., CT - Tax Consultant, Lecturer (Finance, Accounting and Tax), Tax Lecturer at the Faculty of Business Economics Budi Luhur University Jl. Ciledug Raya, Petukangan Utara, Jakarta Selatan, 12260. DKI Jakarta, Indonesia 